\title{
UDP-glucose Pyrophosphorylase from Tubers of Jerusalem Artichoke (Helianthus tuberosus L.)
}

\author{
Kiyotaka OtozaI, Hajime Taniguchi and Michinori NaKamura \\ Department of Agricultural Chemistry, The University of Tokyo, Bunkyo-ku, Tokyo \\ Received July 20, 1972
}

\begin{abstract}
UDP-glucose pyrophosphorylase of Jerusalem artichoke tubers was purified 90 -fold over the crude extract. The purified enzyme preparation absolutely required magnesium ions for activity. Cobalt ions were $60 \%$ as effective as magnesium ions; other divalent cations including manganese showed little or no effect. This enzyme had a $\mathrm{pH}$ optimum of 8.5 and a temperature optimum of $40^{\circ} \mathrm{C}$. ATP and UDP inhibited the activity of this enzyme in both forward and backward directions. $K m$ values for UDP-glucose, inorganic pyrophosphate, glucose-1-phosphate and UTP were determined to be $4.45 \times 10^{-4} \mathrm{M}, 2.33 \times 10^{-4} \mathrm{M}, 9.38 \times$ $10^{-1} \mathrm{M}$ and $2.98 \times 10^{-4} \mathrm{M}$, respectively. These results are discussed in comparison with those of UDP-glucose pyrophosphorylases isolated from other plants.
\end{abstract}

It is well known that uridine diphosphate glucose (UDP-glucose) plays an important role in the biosynthesis of many polysaccharides, oligosaccharides including sucrose, and heterosaccharides. UDP-glucose pyrophosphorylase (UTP: $\alpha$-D-glucose-1-phosphate uridylyltransferase, EC 2.7.7.9) which catalyzes the biosynthesis of UDP-glucose has been purified from various mammalian tissues, ${ }^{1 \sim 31}$ microorganisms $^{4 \sim \text { ) }}$ and higher plants. $^{8 \sim 15)}$ Especially, the enzymes from mammalian tissues were studied extensively, and the enzyme from calf liver ${ }^{2)}$ was recently crystallized. Although some studies on the plant UDPglucose pyrophosphorylases concerning their physiological role have been reported, most of these studies were carried out on crude enzyme preparations and the extended studies on the essential properties of plant enzymes are very limited except for the work of Ginsburg ${ }^{9 !}$ who purified the enzyme extensively from mung bean seedlings and studied some of its properties.

Jerusalem artichoke (Helianthus tuberosus L.) belongs to the Compositae family and the tubers contain sucrose and inulin (polyfructosylsucrose). They contain also various nucleotide sugar compounds including UDP-glu$\operatorname{cose}^{16)}$ It seemed, therefore, interesting to purify UDP-glucose pyrophosphorylase from the tubers of Jerusalem artichoke and to study and compare its properties with those of similar enzymes from other origins.

\section{MATERIALS AND METHODS}

Chemicals. UDP-glucose was the kind gift from the Yamasa Shoyu Co., Chosi, Chiba. ADP-glucose, GDP-glucose, TDP-glucose and NADP were purchased from Sigma Chemical Co. U-14C-Glucose-1phosphate $(277 \mathrm{mCi} / \mathrm{mm})$ was purchased from the Radiochemical Center, Amersham.

Enzymes. Phosphoglucomutase ( $\alpha$-D-glucose-1,6diphosphate: $\alpha$-D-glucose-1-phosphate phosphotransferase, EC 2.7.5.1) (100 units/mg) and glucose-6phosphate dehydrogenase (glucose-6-phosphate: NADP oxidoreductase, EC 1.1.1.49) (140 units/mg) were purchased from Boehringer Mannheim, Japan, Co.

\section{Measurement of pyrophosphorylase activity}

Assay 1. The method of Munch-Petersen ${ }^{17}$ ) was used with a slight modification. One $\mathrm{ml}$ of the reaction mixture contained $80.5 \mu$ moles of Tris- $\mathrm{HCl}$ buffer (pH 7.5), $2.0 \mu$ moles of magnesium chloride, $1.0 \mu$ mole of NADP, $1.0 \mu$ mole of UDP-glucose, $1.0 \mu$ mole of inorganic pyrophosphate, 0.084 unit of glucose-6phosphate dehydrogenase, 0.8 unit of phosphoglucomutase and $5 \mu$ l of the enzyme solution to be tested. The reaction was started by the addition of pyrophosphorylase. An increase of the absorbance at $340 \mathrm{~nm}$ was traced for $10 \mathrm{~min}$ at $25^{\circ} \mathrm{C}$ by a Beckman DB 
spectrophotometer.

Assay 2. The reaction mixture contained, in a total volume of $1.0 \mathrm{ml}, 91.5 \mu$ moles of Tris- $\mathrm{HCl}$ buffer (pH 7.5), 2.0 $\mu$ moles of magnesium chloride, $1.0 \mu$ mole of UDP-glucose, $1.0 \mu$ mole of inorganic pyrophosphate and $5 \mu \mathrm{l}$ of the enzyme solution to be tested. After incubation for $10 \mathrm{~min}$ at $25^{\circ} \mathrm{C}$, the reaction was stopped by placing the reaction tubes in a boiling water bath for $5 \mathrm{~min}$. Two hundreds $\mu \mathrm{l}$ of the cooled reaction mixture was added to $810 \mu \mathrm{l}$ of the second reaction mixture containing $70.4 \mu$ moles of Tris- $\mathrm{HCl}$ buffer ( $\mathrm{pH} 7.5$ ), $0.8 \mu$ mole of NADP, $1.6 \mu$ moles of magnesium chloride, 0.8 unit of phosphoglucomutase and 0.084 unit of glucose-6-phosphate dehydrogenase. After $10 \mathrm{~min}$ of incubation at $25^{\circ} \mathrm{C}$, the absorbance at $340 \mathrm{~nm}$ of the reaction mixture was determined.

Assay 3. The reaction mixture contained, in a total volume of $0.5 \mathrm{ml}, 47.4 \mu$ moles of Tris- $\mathrm{HCl}$ buffer ( $\mathrm{pH} \mathrm{7.5),} 1.0 \mu$ mole of magnesium chloride, $0.25 \mu$ mole (containing $0.25 \mu \mathrm{Ci}$ ) of $\mathrm{U}^{-14} \mathrm{C}$-glucose- 1 phosphate, $0.25 \mu$ mole of UTP and $1 \mu \mathrm{l}$ of the enzyme solution to be tested. After $10 \mathrm{~min}$ of incubation at $25^{\circ} \mathrm{C}$, the reaction was stopped by boiling for $1 \mathrm{~min}$ and the reaction products were isolated by paper chromatography using Tôyō Roshi No. 51A and ethyl alcohol: $1 \mathrm{M}$ ammonium acetate $(\mathrm{pH} 3.8)$ (2.5: $1, v / v)$ as the solvent. In this solvent glucose-1phosphate has the same mobility as that of UMP used as a marker. Nucleotides on the dried paper were located with a Manaslu-light (2536 A). The areas having the ultraviolet absorption was cut out and put into vials containing $15 \mathrm{ml}$ of the scintillator $(4 \mathrm{~g}$ of $\mathrm{PPO}(2,5$-diphenyl oxazole) and $0.1 \mathrm{~g}$ of POPOP ( 1,4 -bis-2-(phenyloxazole)-benzene) in 1 liter of toluene). Radioactivity was determined by a Packard Tri-Carb 3315 scintillation spectrometer.

Definition of unit and specific activity. One unit of enzyme was defined as the amount liberating $1 \mu$ mole of product per minute at $25^{\circ} \mathrm{C}$. Specific activity was defined as units of enzyme per mg of protein. Protein concentration was determined by the method of Lowry et al. ${ }^{18}$

\section{RESULTS}

\section{Purification}

All procedures were carried out in a cold room at $4^{\circ} \mathrm{C}$. Enzymatic activity was determined by the assay 1 . Relative protein content in the column effluent was determined by the absorbance at $280 \mathrm{~nm}$.

\section{Preparation of crude extract}

Jerusalem artichoke tubers $(300 \mathrm{~g})$ were homogenized for $2 \mathrm{~min}$ in $300 \mathrm{ml}$ of $0.02 \mathrm{M}$ potassium phosphate buffer ( $\mathrm{pH} 7.5$ ) containing $0.01 \mathrm{M} \mathrm{KCN}, 0.001 \mathrm{M}$ EDTA and $0.001 \mathrm{M}$ $\beta$-mercaptoethanol. The mixture was filtered through cotton gauze and the filtrate was centrifuged at $6000 \times g$ for $30 \mathrm{~min}$ (Step 1).

\section{Protamine sulfate treatment}

To the supernatant solution $(400 \mathrm{ml})$ was added $147 \mathrm{ml}$ of $1 \%$ protamine sulfate in Buffer A $(0.01 \mathrm{M}$ potassium phosphate buffer (pH 7.5) containing $0.01 \mathrm{M} K \mathrm{KCN}, 0.001 \mathrm{M}$ EDTA and $0.001 \mathrm{M} \beta$-mercaptoethanol) (the final concentration of protamine sulfate was $0.25 \%$ ). The mixture was kept in an ice water for $20 \mathrm{~min}$ and centrifuged for $15 \mathrm{~min}$ at $6,000 \times g($ Step 2).

\section{Ammonium sulfate fractionation}

To the supernatant solution from Step 2 was added solid ammonium sulfate to $80 \%$ saturation, the $\mathrm{pH}$ being maintained at 7.5. The precipitate obtained after centrifugation was dissolved in a small volume of cold Buffer $A$ and dialyzed overnight against 2 liters of the same buffer (Step 3).

\section{DEAE-cellulose column chromatography}

The dialyzed solution was subjected to chromatography on a column $(3 \times 40 \mathrm{~cm})$ of DEAE-cellulose previously equilibrated with Buffer A. The column was then washed with $500 \mathrm{ml}$ of Buffer A. The protein was eluted by continuously increasing the concentration of $\mathrm{NaCl}$ in Buffer $\mathrm{A}$ from 0 to $0.2 \mathrm{M}$ and $7-\mathrm{ml}$ fractions were collected. Fractions having the enzymatic activity were combined and the enzyme was precipitated by $80 \%$ saturation of ammonium sulfate (Step 4). The precipitate was dissolved in a small volume of Buffer A, dialyzed as described above and was subjected to second DEAE-cellulose column chromatography $(1.5 \times 18 \mathrm{~cm})($ Step 5$)$.

\section{Sephadex G-200 gel filtration}

The enzymatically active fractions obtained in Step 5 were applied to a column $(1.6 \times 18 \mathrm{~cm})$ of Sephadex G-200 previously equilibrated 
Table I. Results of Purification

\begin{tabular}{llccccc}
\multicolumn{1}{c}{ Step } & $\begin{array}{c}\text { Volume } \\
(\mathrm{ml})\end{array}$ & $\begin{array}{c}\text { Total } \\
\text { protein } \\
(\mathrm{mg})\end{array}$ & $\begin{array}{c}\text { Total } \\
\text { activity } \\
(\text { units })\end{array}$ & $\begin{array}{c}\text { Specific } \\
\text { activity } \\
\text { (units/mg) }\end{array}$ & $\begin{array}{c}\text { Recovery } \\
(\%)\end{array}$ \\
\hline 1 & Crude extract & 440 & 3390 & 1656 & 0.489 & 100 \\
2 & Protamine sulfate & 570 & 2450 & 1840 & 0.751 & 111 \\
3 & 0 80\% (NH (N) $_{4} \mathrm{SO}_{4}$ & 82 & 1566 & 969 & 0.619 & 58.6 \\
4 & 1st DEAE-cellulose & 220 & 127.5 & 741 & 5.81 & 44.8 \\
5 & 2nd DEAE-cellulose & 7.7 & 20.8 & 200 & 9.62 & 12.1 \\
6 & Sephadex G-200 pool & 11 & 4.73 & 139 & 29.4 & 8.39 \\
& Sephadex peak fraction & 1.9 & 0.76 & 32.1 & 42.2 & 1.94 \\
\hline
\end{tabular}

with Buffer A. The protein was eluted with the same buffer and $1.9 \mathrm{ml}$ fractions were collected at the flow rate of $2.95 \mathrm{ml} / \mathrm{hr}$. Fractions having the highest specific activity were combined (Step 6).

The result of the purification steps is summarized in Table I. The enzyme was purified about 90 -fold at the final step. The purified enzyme was very stable and did not lose its activity after storage for 2 months at $4^{\circ} \mathrm{C}$.

\section{Properties of the purified enzyme}

For the determinations of $K m$ values for glucose-1-phosphate and UTP, and of the equilibrium constant of pyrophosphorylase reaction, Assay 3 was used. In all others, the enzymatic activity was determined by Assay 2 .

\section{Linearity of the reaction}

The enzymatic reaction proceeded lineary up to about $32 \%$ of UDP-glucose.

\section{Effect of metal ions}

This enzyme absolutely required magnesium ions for its activity. The optimum concentration was $1.5 \mathrm{~mm}$ as shown in Fig. 1. Other metal ions had little or no effect on this enzyme (Fig. 2).

\section{Effect of $p H$}

The optimum $\mathrm{pH}$ of the enzyme was determined to be 8.5 as shown in Fig. 3. Citrate buffer was found to be inhibitory to this enzyme.

\section{Effect of temperature}

The enzyme showed the maximum activity

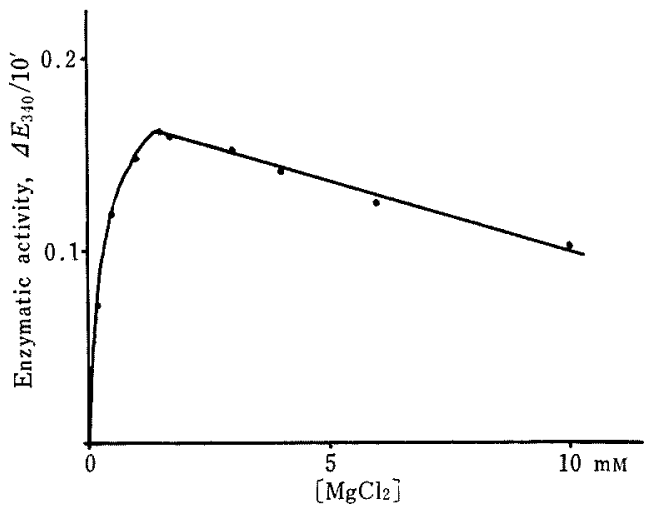

FIG. 1. Effect of the Concentration of Magnesium Ions on the UDP-glucose Pyrophosphorylase Reaction. The enzymatic activity was measured with Assay 2 except the reaction mixture of the first step contained from 0 to $10 \mathrm{~mm}$ of magnesium chloride. See Assay 2 in the Measurement of pyrophosphorylase activity for other details.

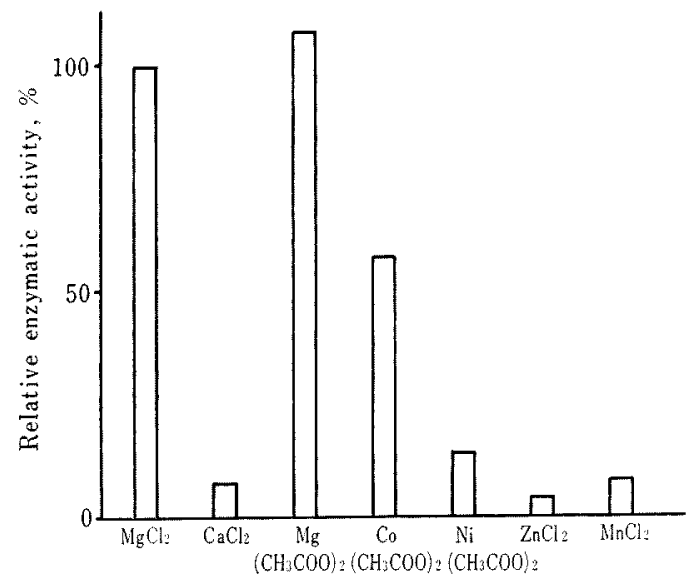

Fig. 2. Effect of Metal Ions on the UDP-glucose Pyrophosphorylase Reaction.

The enzymatic activity was measured with Assay 2. $2 \mathrm{~mm}$ of each metal ion was added to the reaction mixture of the first step of Assay 2 in place of magnesium chloride. For other details, see the text. 


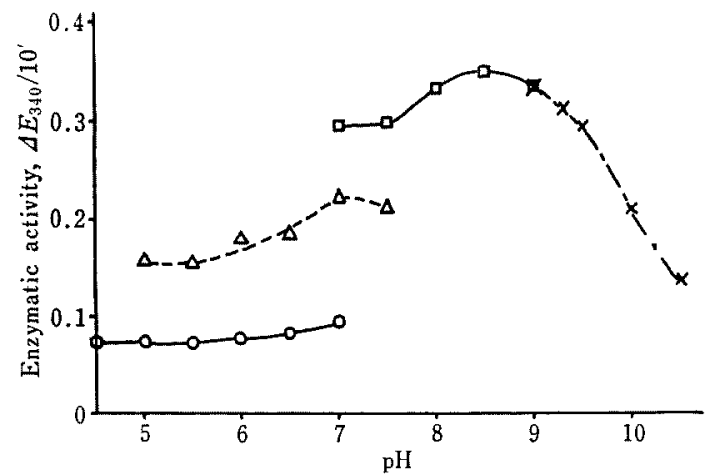

FIG. 3. Optimum pH of UDP-glucose Pyrophosphorylase Reaction.

The enzymatic activity was measured with Assay 2, except buffers with various $\mathrm{pH}$ values as shown in the figure were used in the first step. Buffers used (all at $0.01 \mathrm{M}$ ) were phosphate $(\Delta-\Delta)$, citrate $(\mathrm{O}-\mathrm{O})$, Tris $(\square-\square)$, and glycine $(x-x)$.

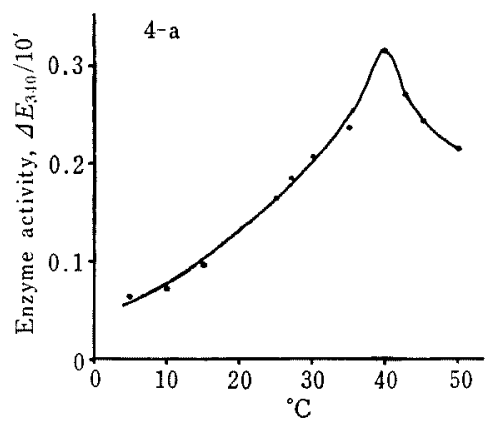

Fig. 4-a. Effect of Temperature on the UDP-glucose Pyrophosphorylase Reaction.

The enzymatic activity was measured with Assay 2 except the reaction of the first step was carried out at temperatures as shown in the figure.

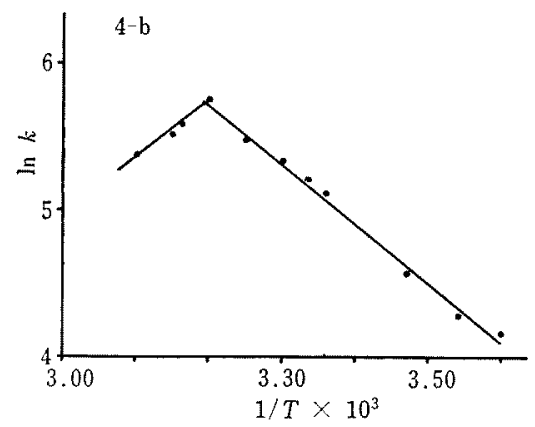

Flg, 4-b. The Arrhenius Plot of Fig. 4-a.

at $40^{\circ} \mathrm{C}$ as shown in Fig. 4 a. The activation energy, calculated from the Arrhenius plot as shown in Fig. 4-b, was $7.9 \mathrm{kcal} /$ mole.
Table II, Determination of the Equilibrium CONSTANT, (Keq), OF THE UDP-Glucose BIOSYNTHESIS AT pH 7.5 AND AT $25^{\circ} \mathrm{C}$.

Assay 3 was used. Keq was calculated by the equation, Keq $=\frac{[\text { UDP-glucose][PPi] }}{\text { [Glucose-1-P][UTP] }}$. It was assumed that the changes of the concentration of UDPglucose and UTP on the one hand, and of glucose1-P and PPi on the other, are equal, respectively.

\begin{tabular}{rccc}
\hline $\begin{array}{r}\text { Time } \\
(\mathrm{min})\end{array}$ & $\begin{array}{c}\text { Glucose-1-P } \\
(\mathrm{M})\end{array}$ & $\begin{array}{c}\text { UDP-glucose } \\
(\mathrm{M})\end{array}$ & Keq \\
\hline 0 & 0.242 & 0.008 & 0.0109 \\
5 & 0.221 & 0.029 & 0.0172 \\
10 & 0.205 & 0.045 & 0.0482 \\
30 & 0.174 & 0.076 & 0.191 \\
60 & 0.178 & 0.072 & 0.163 \\
90 & 0.175 & 0.075 & 0.184 \\
120 & 0.178 & $\mathbf{0 . 0 7 2}$ & 0.163 \\
240 & 0.178 & $\mathbf{0 . 0 7 2}$ & 0.163 \\
1080 & 0.177 & $\mathbf{0 . 0 7 3}$ & 0.170 \\
\hline
\end{tabular}

\section{Substrate specificity}

No enzymatic activity was detected with ADP-glucose, GDP-glucose or TDP-glucose in place of UDP-glucose.

\section{Substrate concentration}

The effects of the concentration of the substrates are shown in Fig. 5. The Michaelis constants $(\mathrm{Km})$ determined by the LineweaverBurk $^{19)}$ plot of the above data were $4.45 \times$ $10^{-4} \mathrm{M}$ for UDP-glucose, $2.33 \times 10^{-4} \mathrm{M}$ for inorganic pyrophosphate, $9.38 \times 10^{-4} \mathrm{M}$ for glucose-1-phosphate and $2.98 \times 10^{-4} \mathrm{M}$ for UTP.

\section{Equilibrium of the reaction}

From the data presented in Table II, the equilibrium constant of the reaction, Keq= (glucose - 1 - phosphate) (UTP) / (UDP - glucose) (inorganic pyrophosphate), was calculated to be 0.16 .

\section{Inhibitors and activators}

The effect of several substances on this enzyme are shown in Fig. 6. Sugars and glycolytic intermediates had little or no effect. ATP and UDP had significantly inhibitory effect on this enzyme. 

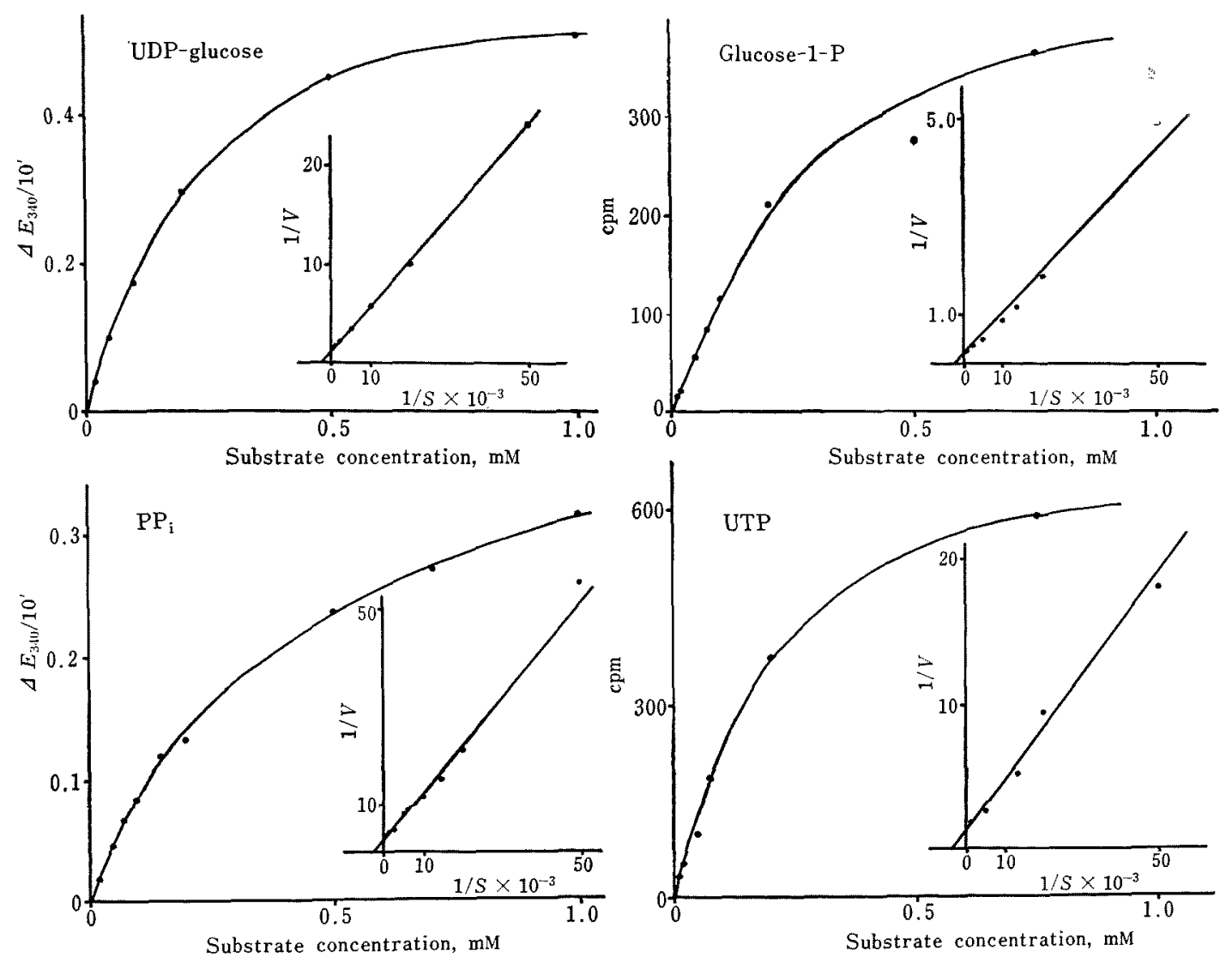

FIG. 5. Effect of Substrate Concentration on Enzymatic Activity.

The saturation curves of UDP-glucose and PPi were obtained by using Assay 2 and the saturation curves of glucose-1-P and UTP were obtained by using Assay 3. Other experimental details are given in Measurement of pyrophosphorylase activity.

\section{DISCUSSION}

Although our preparation, at the present state of purification, is not apparently homogeneous as judged by polyacrylamide gel electrophoresis, it is one of the most purified plant UDP-glucose pyrophosphorylases ever described, except that of Ginsburg ${ }^{9}$ whose purified enzyme far surpassed the specific activity of the crystalline calf liver enzyme. ${ }^{23}$ No further purification of our preparation was obtained by the routine techniques of protein purification.

Neufeld et $a l .^{8)}$ reported that magnesium, manganese and cobalt ions, each at a concentration of $3.3 \mathrm{~mm}$, gave the same activity on the mung bean UDP-glucose pyrophosphorylase, and Turner and Turner ${ }^{11)}$ reported that magnesium ions at a concentration of $5 \mathrm{~mm}$ and manganese ions at a concentration of $1 \mathrm{~mm}$ gave the same effect on the pea seed enzyme. But, with our preparation, manganese ions at a concentration of $2 \mathrm{~mm}$ gave little effect whereas cobalt ions at the same concentration were about $60 \%$ as effective magnesium ions. In addition, many reports have appeared which showed various effects of manganese and cobalt ions on UDPglucose pyrophosphorylases from animals and microorganisms. It can not be decided at present whether these differences are regarded as the nature of these enzymes or caused by the different degree of purification. 


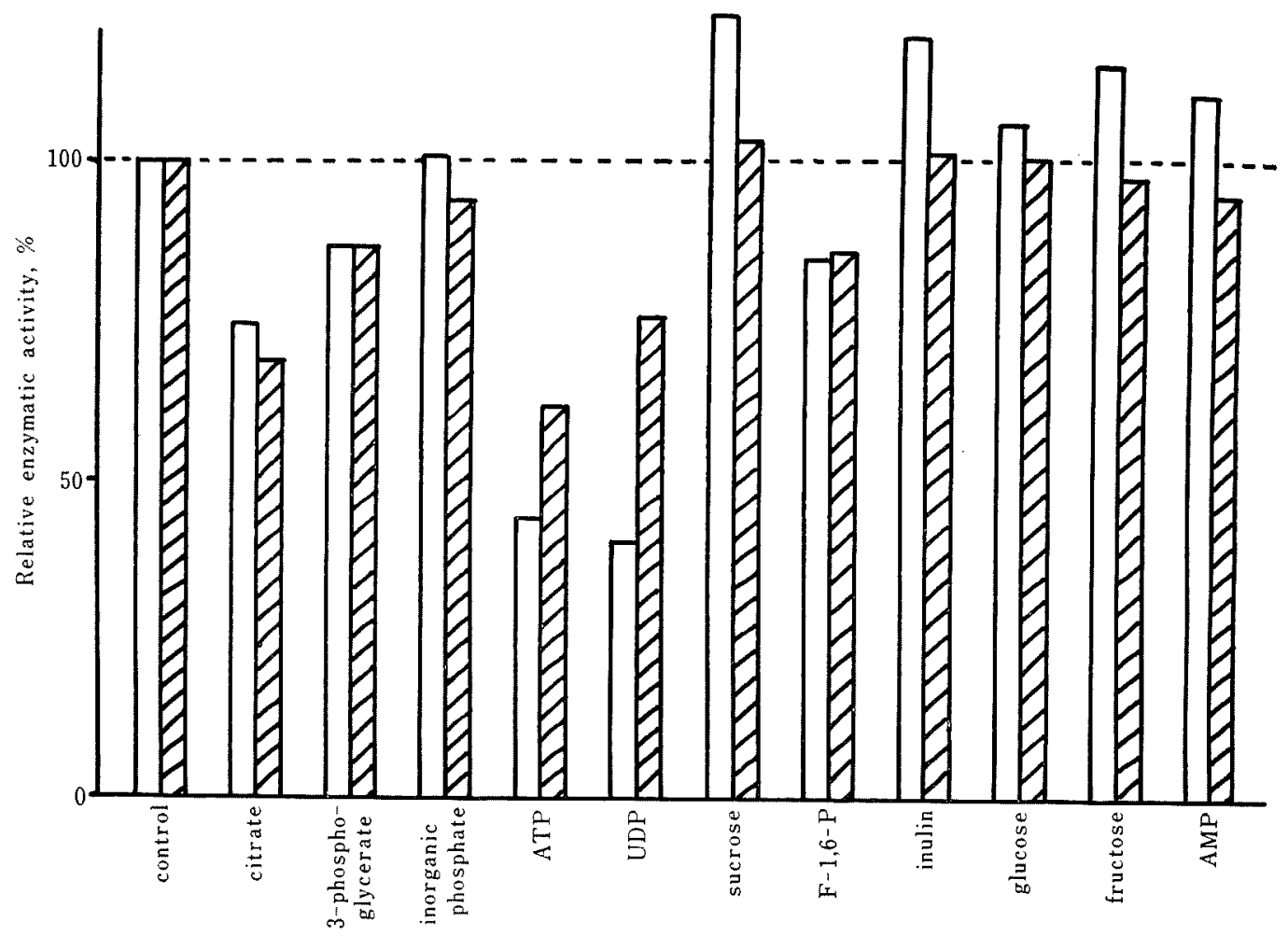

FIG. 6. Effect of Inhibitors and Activators on the UDP-glucose Pyrophosphorylase Reaction.

For the details see the text. $\square$ UDP-glucose $+P^{-} \longrightarrow U T P+G-1-P$. In this direction Assay 2 was used. $[/ / 1 \mid$ UTP $+\mathrm{G}-1-\mathrm{P} \longrightarrow$ UDP-glucose $+\mathrm{PPi}$. In this direction Assay 3 was used.

Almost all the UDP-glucose pyrophosphorylases ever known showed maximum activity at an alkaline $\mathrm{pH}$. Arai and Fujisaki ${ }^{14}$ investigated the UDP-glucose pyrophosphorylases from various higher plants and reported that all the enzymes from storage tissues showed the maximum activity at $\mathrm{pH} 9.0 \sim 9.5$. However, our enzyme had a slightly lower optimum $\mathrm{pH}$ at 8.5 and a shoulder at $\mathrm{pH} 7.0 \sim 7.5$. This may suggest the presence of isomers of UDPglucose pyrophosphorylase in our preparation.

Regarding the substrate affinity of UDPglucose pyrophosphorylases from plant origins, following $\mathrm{Km}$ values have been reported: $1 \times 10^{-3} \mathrm{M}$ for glucose-1-phosphate (wheat $\left.{ }^{13}\right)$, $1.1 \times 10^{-4} \mathrm{M}$ for UDP-glucose and $2.3 \times 10^{-4} \mathrm{M}$ for inorganic pyrophosphate (mung bean seedlings $\left.{ }^{9}\right)$. Our enzyme has approximately the same $K m$ values as those described above. On the contrary, the $K m$ values of similar enzymes prepared from animals have been reported to be of the order of $10^{-5} \mathrm{M}$. It may be pointed out that the plant UDP-glucose pyrophosphorylases have larger $\mathrm{Km}$ values than those of animal enzymes and that in the plant enzymes the $K m$ value for glucose-1phosphate is larger than those for other substrates.

Glycolytic intermediates did not show any effect on our UDP-glucose pyrophosphorylase in accordance with the results of similar enzymes from other various organisms. ATP and UDP inhibited the enzyme both in forward and backward directions. Structural analogy of these substances to the substrates can not explain the above inhibition. To elucidate the exact mechanism of this inhibition, more detailed kinetic studies are needed.

After this article had been submitted for publication, a report ${ }^{20}$ concerning the UDPglucose pyrophosphorylase from Sorghum vulgare appeared. 
Acknowledgements. Thanks are due to Drs. Kinzo Kawatei, Ryuichi Ishii and Hiroshi Ina of the Tanashi Farm for cultivating Jerusalem artichoke for us.

\section{REFERENCES}

1) C. Villar-Palasi and J. Larner, Arch. Biochem. Biophys., 86, 61 (1960).

2) G. J. Albrecht, S. T. Bass, L. L. Seifert and R. G. Hansen, J. Biol. Chem., 241, 2968 (1966).

3) K. K. Tsuboi, K. Fukunaga and J. C. Petricciani, ibid., 244, 1008 (1969).

4) A. Kamogawa and K. Kurahashi, J. Biochem., 57, 758 (1965).

5) T. Nakae and H. Nikaido, J. Biol. Chem., 246, 4386 (1971).

6) T, Nakae and H. Nikaido, ibid., 246, 4357 (1971).

7) T. Nakae, ibid., 246, 4404 (1971).

8) E. F. Neufeld, V. Ginsburg, E. W. Putman, D. Fanshier and W. Z. Hassid, Arch. Biochem. Biophys., 69, 602 (1957).

9) V. Ginsburg, J. Biol. Chem., 232, 55 (1958).
10) N. C. Ganguli, J. Biol. Chem., 232, 337 (1958).

11) D. H. Turner and J. F. Turner, Biochem. J., 69, 448 (1958).

12) M. A. Hall and L. Ordin, Physiol. Plant, 20, 624 (1967).

13) K. C. Tovey and R. M. Roberts, Plant Physiol, 46, 406 (1970).

14) Y. Arai and M. Fujisaki, Bot. Mag. Tokyo, 84, 76 (1971).

15) J. F. Hopper and D. B. Dickinson, Arch. Biochem. Biophys., 148, 523 (1972).

16) H. Taniguchi, Y. Umemura and M. Nakamura, Agr. Biol. Chem., 31, 231 (1967).

17) A. Munch-Petersen, Acta Chem. Scand., 9, 1523 (1955).

18) O. H. Lowry, N. J. Rosebrough, A. L. Farr and R. J, Randall, J. Biol. Chem., 193, 265 (1951).

19) H. Lineweaver and D. Burk, J. Am. Chem. Soc., 56, 658 (1934).

20) G. L. Gustafson and J. E. Gander, J. Biol. Chem., 247, 1387 (1972). 